\title{
REVITALISASI DALAM FLUKTUASI KESENIAN REOG PONOROGO MENUJU ICON KABUPATEN DAERAH TINGKAT II PONOROGO
}

\author{
Luh Putu Kerti Pujani ${ }^{1}$
}

\begin{abstract}
The art performance know as Reog Ponorogo is based on folklore which is certainty believed by Ponorogo Community. Reog Ponorogo consists of historical/ancestral values which are represented through specific symbols in that art performance. In it's development Reog Ponorogo has diachronic side, fluctuated between growth and fall, well described as alienated and marginalized. Those situations were caused by domination of colonial government and political movement. The turning point was made by ingenuity of traditional Muslim student that performed "gajah-gajahan” art performance which similar to act of Reog in the period of the second fall phase caused by domination of colonial regime. Nowadays, the intensity of revitalization, contruction, reproduction is conducated by preserving the dance on village community level and also revotalization action formally by The Ponorogo regency. Thus, Reog is reproduced to achieve a distinctive existence and becomes an icon of Ponorogo area.
\end{abstract}

Keywords: revitalization and continuous

Haviland mengungkapkan bahwa, cerita merupakan salah satu bentuk kesenian verbal yang paling mudah dipublikasikan, karena memiiki daya tarik populer. Dalam kebudayaan Barat cerita rakyat mendapat

${ }^{1}$ Luh Putu Kerti Pujani adalah Dosen Fakultas Sastra Universitas Udayana Denpasar. 
perhatian paling besar untuk dipelajari. Cerita rakyat dapat dibedakan menjadi tiga katagori yaitu: mitos, legenda dan dongeng (Soekadijo, 1993: 228).

Mitos pada dasarnya bersifat religius, karena memberi ratio pada kepercayaan. Masalah-masalah yang dibicarakan adalah masalah pokok kehidupan manusia seperti: dari mana asal kita, mengapa kita disini dan kemana tujuan kita. Setiap aspek masalah yang sangat luas tersebut di atas dapat disebut mitos. Fungsi mitos adalah menerangkan. Di antaranya memberi gambaran perilaku yang teratur (Soekadijo, 1993: 227-229).

Berdasarkan pengertian mitos tersebut di atas, Reog Ponorogo cenderung bisa dikatagorikan sebagai mitos karena, cerita reog mengarah pada pemaparan sejarah reog terkait dengan daerah Ponorogo, dan sarat dengan simbol-simbol yang menyandikan makna budaya perilaku yang teratur. Kesenian Reog pada dasarnya merupakan media edukatif yang komunikatif bagi masyarakat Ponorogo. Sehingga muncul bahasa lokal yang mengemukakan bahwa reog merupakan "tontonan sekaligus tuntunan”. Tuntunan mengarah pada enkulturasi, menginstitusikan pengetahuan untuk memerangi kesewenang-wenangan dalam hidup bermasyarakat, budi pekerti, dan etika kepemimpinan.

Reog sebagai kesenian unggulan daerah Ponorogo, bahkan unggulan daerah Jawa Timur mengalami fluktuasi dalam alur perjalanannya dari waktu ke waktu. Salah satu contoh peristiwa pada masa kemerdekaan (setelah tahun 1945) kesenian Reog Ponorogo mengalami masa kejayaan. Namun kemudian pada tahun 1965 mengalami keterasingan dan berjarak dengan masyarakat pendukungnya. Demikian, irama seperti ini berulang dalam beberapa periode. Kemudian pasca tahun 1968 masyarakat Ponorogo mulai melakukan revitalisasi pada tahap awal terhadap kesenian Reog Ponorogo. Intensitas revitalisasi dan sosialisasi semakin ditingkatkan. Akhirnya sampai pada digelarnya festival reog tahunan pada Satu Suro. Festival Satu Suro merupakan ajang kompetisi, upaya rekonstruksi kualitas grup reog di tingkat regional, nasional, utamanya grup reog asal Ponorogo. Langkah-langkah revitalisasi Reog Ponorogo mengarah pada memposisikan reog sebagai icon Daerah Tingkat II Ponorogo. Reog dipergunakan sebagai duta kesenian Jatim di tingkat internasional. Di samping itu juga dipergunakan sebagai daya tarik wisata daerah Ponorogo. 
Kesenian Reog Ponorogo yang mengandung nilai-nilai kebijaksanaan, memiliki kekhasan, merupakan kesenian unggulan daerah Ponorogo idealnya dijaga kontinuitasnya. Sehingga fluktuasi image yang mengancam kontinuitas kesenian reog dapat dihindari. Action revitalisasi dalam fluktuasi kesenian reog Ponorogo, sebagai titik balik kesenian Reog Ponorogo menuju kemapanan dalam masyarakat Ponorogo. Lebih jauh lagi menuju kemapanan di tingkat nasional ataupun internasional.

Dalam hal ini satu pemikiran penting yang perlu diperhatikan adalah bahwa; kebudayaan manusia termasuk seni budayanya memiliki sisi diakronis. Herskovits menegaskan bahwa "no living culture is static". Karakteristik dasar dari budaya mengarah pada adanya semacam paradoks yaitu: Culture is stable, yet culture is also dynamic. Maka dari itu pendukung suatu budaya tertentu idealnya mampu mencermati unsurunsur budaya unggulan yang dimilikinya. Yang pada dasarnya mengandung nilai-nilai luhur masyarakat atau komunitas tertentu, memiliki kekhasan, selanjutnya dijaga keberlanjutannya, sebagai implementasi rasa tanggung jawab pada generasi mendatang. Dimensi ideal dari kebudayaan diupayakan untuk dipertahankan. Pendekatan diakronis terhadap Reog Ponorogo dalam tulisan ini ditopang dengan prosedur kerja metodologis penelusuran data sekender, melalui teknik dokumen (Wija, 1993: 47). Kartodirjo mengemukakan bahwa ilmu-ilmu sosial perlu mempergunakan bahan dokumenter, pada dasarnya masyarakat sekarang adalah hasil dari suatu proses diakronis, berupa proses perkembangan melalui fase-fase (Kartodirdjo, 1977: 23).

\section{REVITALISASI KESENIAN}

Revitalisasi movements merupakan gerakan kebangkitan. Gerakan kebangkitan merupakan suatu usaha yang disadari oleh anggota masyarakat untuk membentuk suatu kebudayaan yang lebih memuaskan. Hal ini berlaku pada seluruh komponen sistem kebudayaan.

Ahli antropologi Wallace merumuskan urutan umum dalam proses kebangkitan (revitalisasi) adalah sebagai berikut: (a) keadaan normal masyarakat, ada dominasi kelompok, stres yang bertambah besar; (b) apabila tidak terjadi perubahan-perubahan adaptif maka mulailah pada periode kerusakan/stagnasi pada titik tertentu; dan (c) dibutuhkan periode kebangkitan. Pada waktu itu sering berupa gerakan kultus keagamaan 
yang dinamis mempesona bagian penduduk yang cukup besar. Sering gerakan ini tidak sesuai dengan keadaan nyata (Soekadijo, 1993: 31).

Tampaknya semua peradaban berjalan melalui kemiripan siklus proses-proses kejadian; pertumbuhan, keruntuhan (gejala kritis atau keterasingan) dan disintegrasi. Menurut Toynbee terjadinya suatu peradaban terdiri dari suatu transisi dari kondisi statis ke aktivitas dinamis, hal ini mungkin terjadi karena spontan. Tantangan dari lingkungan sosial memancing tanggapan kreatif dalam suatu masyarakat, yang berhasil membangkitkan momentum budaya (Capra, 1997: 11-13).

Seni adalah penggunaan kreatif imajinasi manusia untuk menerangkan, memahami suatu kehidupan. Adapun fungsi kesenian, mitos misalnya, menentukan norma untuk perilaku yang teratur. Mitos pada dasarnya bersifat religius, karena memberi ratio pada kepercayaan. Masalah yang dibicarakannya adalah masalah-masalah pokok kehidupan manusia seperti; dari mana asal kita, dan kemana tujuan kita. Setiap aspek masalah-masalah yang sangat luas tersebut, bisa disebut mitos. Fungsi mitos adalah untuk menerangkan, memberi penjelasan tetang perilaku yang teratur (Soekadijo, 1993: 42).

Pemahaman terhadap makna seni budaya dicermati dari perspektif teori relasional. Teori relasional mencoba menemukan hubunganhubungan di antara simbol-simbol budaya, peristiwa budaya, untuk mencapai pemahaman terhadap makna budaya itu sendiri. Ada beberapa penegasan tentang dasar teori relasional di antaranya adalah: sistem makna budaya disandikan dalam simbol-simbol; dan bahasa merupakan sistem simbol utama yang menyandikan makna budaya dalam setiap masyarakat (Pujani, 2000: 112).

Simbol atau tanda dapat dilihat sebagai konsep. Bentuk primer dari simbolisasi oleh manusia adalah melalui bahasa. Manusia berkomunikasi dengan menggunakan tanda, simbol dalam lukisan, tarian, musik, mimik wajah, arsitektur, pemilikan barang dan seterusnya. Simbol memberi landasan bagi tindakan dan perilaku, selain gagasan dan nilainilai (Saifuddin, 2005: 289-296). Menurut Spradley, simbol adalah objek atau peristiwa yang merujuk pada sesuatu. Semua simbol melibatkan tiga unsur: simbol itu sendiri, satu rujukan atau lebih, dan hubungan antara simbol dan rujukan (Spradely, 1997: 121). Rujukan adalah pemikiran terkait dengan pengalaman manusia. 


\section{KOMPONEN PEMENTASAN KESENIAN REOG PONOROGO}

Komponen-komponen yang merupakan tari dasar pementasan Reog Ponorogo adalah: (a). tari lepas (terdiri dari; tari warok, tari jathilan, tari pujangganong, tari klana sewandana, dan tari barongan); (b). tari merak tarung; dan (c). tari iring-iringan panaragan.

\section{1). Tari Warok}

Warok merupakan bagian peraga dari kesenian reog Ponorogo. Keterkaitan antara reog dengan warok sangat erat, dimana ada kesenian Reog Ponorogo disitu ada warok. Warok adalah: seseorang yang menguasai ilmu lahir maupun batin (wong sing biso mumpuni salwiringreh, agal alus). Warok dapat dipilah atas tiga yaitu; warok tua, warok muda dan warokan. Adapun ciri-ciri seorang warok pada umumnya adalah sebagai berikut:

a). Personel berilmu dan sakti, namun tidak untuk diri pribadi, melainkan untuk kepentingan keluarga dan masyarakat lingkungannya.

b). Berjiwa pengayom, rela berkorban untuk kepentingan umum

c). Suka bekerja keras tanpa pamrih

d). Berwatak jujur dan bertanggung jawab (yen lemes kena kanggo tali, yen kaku kena kanggo pikulan).

e). Bersikap ing ngarso sung tuladha, ing madya mangun karsa, tut wurihandayani. Bersikap adil, suka mengalah, lembut, tetapi tegas dalam pendirian.

Warok tua merupakan penanggung jawab, pengayom dalam kesenian Reog Ponorogo. Pada dasarnya figur warok merupakan kebanggaan masyarakat Ponorogo. Sifat-sifat warok diimplementasikan dalam gerak tari warok.

\section{2). Tari Jathilan}

Tari jathilan atau biasa disebut tari jaranan adalah menggambarkan nilai-nilai ketangkasan prajurit berkuda yang sedang berlatih perang di atas kuda. Tarian ini dibawakan berpasangan. 


\section{3). Tari Pujangganong}

Merupakan figur patih Pujangga Anom yang selalu tegar, ceria, dan humoris. Ia merima perintah Prabu Klana Sewandana untuk melamar putri Kediri. Menurut cerita hari keberangkatannya ke kediri merupakan hari naas bagi patih Pujangga Anom, namun ia menempatkan perintah raja di atas kepentingan pribadinya. Dalam diri Pujangga Anom telah terinstitusi sifat rela berkorban, semangat pengabdian demi negara/ kerajaan. Siap melaksanakan tugas dengan penuh tanggung jawab. Sifatsifat patih Pujangga Anom diimplementasikan melalui gerak tari Pujangganong.

\section{4). Tari Kana Sewandana}

Prabu Klana Sewandana adalah seorang raja sakti, yang masih muda dan tampan. Beliau memiliki pusaka cemeti bernama Kyai Pecut Samandiman, yang diandalkan untuk melindungi dirinya. Sang prabu sedang mabuk asmara terhadap putri Kediri. Gerak tari menggambarkan kelincahan, berwibawa dan menggambarkan seseorang yang sedang kasmaran.

\section{5). Tari Barongan}

Gerak tari barongan pada prinsipnya menggambarkan atau menirukan gerak-gerik seekor harimau. Barongan dimainkan dengan posisi jongkok.

\section{6). Tari Merak Tarung}

Menggambarkan gerak-gerik dua ekor burung merak yang sedang bertarung. Dalam pementasan tari merak tarung, harus dimainkan oleh dua orang penari putra. Adapun peralatan yang dipergunakan adalah dhadhak merak dengan memakai kepala barongan. Alur tari merak tarung adalah sebagai berikut: (a) tarung antara dua dhadhak merak; (b) tarung dua dhadhak merak dengan dua jathilan; (c) tarung dua dahdhak merak dengan Pujangganong; dan (d) tarung dua dhadhak merak dengan Klana Sewandana. Barongan dimainkan dalam posisi berdiri.

\section{7). Tari Iring-iringan Panaragan}

Tari iring-iringan merupakan ragam gerak tari dengan posisi berjalan beriringan. Seluruh komponen tari reog berjalan beriringan. 
Pada intinya tari ini adalah lanjutan dari tari utuh merak tarung (Pemkab Ponorogo, 1996).

Hal lain yang perlu dicermati dalam kesenian Reog Ponorogo adalah, makna budaya yang disandikan melalui aspek busana khususnya pada warna busana. Warna-warna yang menonjol dalam tata busana reog antara lain: warna hitam, merah, putih, dan kuning.

a). warna hitam menyandikan sifat berwibawa, tenang dan berisi. Di samping itu juga menyandikan pengendalian nafsu aluamah.

b). warna merah menyandikan sifat berani, dan pengendalian nafsu amarah.

c). warna putih menyandikan kesucian dan pengendalian nafsu mutmainah.

d). warna kuning menyandikan kejayaan, kebahagiaan dan pengendalian nafsu supiah.

Busana khas personel penari reog dipergunakan sebagai pakaian daerah masyarakat Ponorogo. Di samping itu Pemerintah Daerah Tingkat II Ponorogo menggunakan pakaian tersebut sebagai pakaian resmi dalam menghadiri acara yang bersifat kedaerahan di kabupaten Ponorogo (Utami, 2007: 13).

Busana Reog Ponorogo merupakan simbol yang menyandikan makna budaya dalam koridor budi pekerti dan pengendalian diri, sehingga memiliki kemapanan tertentu dalam kehidupan bermasyarakat di daerah Ponorogo. Sistem makna budaya masyarakat Ponorogo disandikan dalam simbol-simbol pentokohan, gerak tari (body tolk), dan busana tokoh-tokoh reog. Beberapa makna budaya lainnya yang terkandung dalam kesenian reog adalah: (a) etika kepemimpinan disandikan dalam tokoh patih Pujangga Anom; prabu Kelana Sewandodo, dan Singobarong; dan (b) tasbih diujung paruh merak mengandung makna islami.

Peralatan reog berjumlah 17 menyandikan bahwa umat Islam wajib menyembah Allah dalam sehari 17 rakaat (Pemkab Ponorogo, 1996). 


\section{REVITALISASI KESENIAN REOG PONOROGO}

\section{Sejarah Reog Ponorogo}

Pada zaman dulu dikisahkan ada kerajaan bernama Bantarangin, yang dipimpin oleh seorang raja yang bergelar Prabu Kelono Sewandono. Prabu Kelono Sewandono mempunyai abdi di antaranya adalah: patih Pujangga Anom, pasukan berkuda (jathilan) dan abdi dalem Poetro Djoyo dan Poetro Tholo.

Kemudian diceritakan Prabu Kediri ingin menikahkan putrinya Dewi Songgolangit, dengan menyelenggarakan sayembara. Berita akan diselenggarakannya sayembara di kerajaan Kediri sampai ke kerajaan Bantarangin. Sang Prabu Bantarangin segera mengutus patih Pujangga Anom menuju Kediri untuk mendapat kepastian tentang penyelenggaraan sayembara tersebut. Sesampainya di kerajaan Lodoyo (di daerah Belitar), patih Pujangga Anom dihadang oleh penguasa hutan Ludoyo yaitu Prabu Singobarong,dengan niat ingin menggagalkan misi Pujangga Anom menuju Kediri. Karena pada dasarnya Singobarongpun punya keinginan yang sama datang ke Kediri untuk meminang Dewi Songgolangit. Maka terjadilah perang antara Singobarong dengan patih Pujangga Anom, yang pada akhirnya dimenangkan oleh Singobarong. Pujangga Anom melarikan diri menuju Bantarangin untuk melaporkan peristiwa ini kepada Prabu Kelono Sewandono. Sang prabu Bantarangin segera mengerahkan seluruh kekuatan wadya bala (prajurit), untuk memerangi Singobarong. Akhirnya perang yang lebih dahsyatpun terjadi di kerajaan Ludoyo. Raja Bantarangin bertarung dengan raja Lodoyo. Prabu Kelono Sewandono sempat terdesak, pada saat itu patih Pujangga Anom cepat menyerahkan Cemeti Samandiman, cemeti handalan untuk melindungi diri Prabu Kelono Sewandono. Singobarongpun dapat ditaklukkan, namun ia cepat minta ampun agar tidak dibunuh. Prabu Kelono Sewandono mengabulkan permintaannya dengan satu syarat yaitu; Singobarong siap dijadikan hadiah atau mas kawin untuk meminang Dewi Songgolangit. Pada saat Singobarong mengalami kekalahan , burung merak peliharaannya mendatanginya dan hinggap di kepalanya sambil mengepakkan sayapnya.

Kemudian rombonganpun melanjutkan perjalanannya menuju Kediri mengawal Prabu Kelono Sewandono mengikuti sayembara. Pada saat semua menanti keputusan sayembara, berupa keputusan Dewi Songgolangit, pada momen ini Prabu Kelono Sewandono 
menghadiahkan Dewi pertunjukan tari-tarian yang diperagakan oleh Singobarong dan burung meraknya yang hinggap di atas kepala Singobarong.

Untuk mengenang momen ini masyarakat Bantarangin (masyarakat Ponorogo) mengenang pertunjukan Singobarong dengan membuatkan duplikatnya sehingga bisa hidup terus di lingkungan masyrakat Ponorogo. Tarian ini kemudian dikenal dengan Reog Ponorogo (Utami, 2007: 23). Cerita ini diyakini benar-benar terjadi di lingkungan masyarakat Ponorogo yang merupakan bagian dari kerajaan Majapahit (Pemkab Ponorogo, 1996). Kesenian Reog Ponorogo memiliki kemapanan tertentu di lingkungan masyarakat Ponorogo.

Paparan di atas menunjukkan bahwa, Reog Ponorogo dilatarbelakangi oleh cerita rakyat yang mengilustrasikan aspek historis daerah Ponorogo. Simbol-simbol yang terkandung di dalam Reog Ponorogo bersifat menerangkan, memberi gambaran perilaku yang teratur sebagai tuntunan masyarakat Ponorogo.

\section{Revitalisasi dalam Fluktuasi Kesenian Reog Ponorogo}

Kesenian reog yang semakin digemari oleh masyarakat bagian wilayah Majapahit khususnya di Ponorogo. Di Ponorogo reog tumbuh dan berkembang di mana-mana lengkap dengan warok dan gemblaknya. Namun kemudian pada masa penjajahan Belanda dan pendudukan Jepang, kesenian reog mengalami masa surut baik dalam pentas seni maupun dalam aktivitas proses belajar kesenian reog. Hal ini terjadi karena fenomena berkumpul dalam rangka pementasan ataupun proses belajar menari, mengundang kecurigaan pemerintahan penjajah. Oleh karena itu aktivitas berkesenian reog dilarang.

Kesenian reog mulai muncul kembali setelah Indonesia merdeka tahun 1945. Namun sangat disayangkan tahun 1965 kesenian reog dijadikan alat organisasi politik (Pemkab Ponorogo, 1996). Utami (2007) mengemukakan bahwa, tahun 1965 kesenian reog pernah mengalami fluktuasi image sebagai implikasi keterlibatannya dalam kegiatan kampanye partai politik tertentu, sehingga masyarakat pendukung reog stagnasi pada sikap apatis, akhirnya kegiatan berkesenian reog cenderung terhenti. Beberapa seniman reog berpendapat bahwa, masa ini merupakan masa kehancuran kesenian reog.

Kemudian tahun 1968 pihak Nahdhatul Ulama (NU) membuat suatu formulasi kesenian baru yang dinamakan gajah-gajahan. 
Pementasan gajah-gajahan dimainkan oleh para santri, satu personel pemain naik di atas punggung gajah buatan dengan berbusana layaknya seorang khalifah. Diiringi syair puji-pujian shalawat Nabi, dan musik odrot. Selesai pementasan, komponen tari gajah-gajahan berjalan beriringan seperti layaknya kesenian Reog Ponorogo. Ternyata kesenian gajah-gajahan mendapat sambutan baik dari masyarakat Ponorogo.

Kesenian gajah-gajahan mengilhami dan merupakan suatu energi yang memotivasi bangkitnya kesenian Reog Ponorogo. Selanjutnya organisasi Partai Nasional Indonesia (PNI), mendirikan group reog yang dinamakan Barisan Reog Nasional (BRN). Pada periode berikutnya para ulama yang menaruh perhatian besar pada kesenian reog juga ikut mendirikan group reog dengan nama Cabang Kesenian Reog Agama (CAKRA) (Utami, 2007).

Dengan demikian dalam perjalanan waktu gerakan revitalisasi terhadap kesenian Reog Ponorogo mampu mengakrabkan kembali kesenian tersebut dengan masyarakat Ponorogo sebagai komunitas pendukungnya. Implikasi positif dari kondisi ini adalah semakin banyak bermunculan kembali group reog di daerah Ponorogo. Respon tahap lanjut adalah mulai diselenggarakan festival reog untuk memotivasi rekonstruksi kualitas pementasan group-group reog yang bermunculan di daerah Ponorogo.

Tabel 1. Jumlah Padepokan Kesenian Reog Ponorogo di Kabupaten Ponorogo Tahun 2006

\begin{tabular}{|c|l|c|c|c|}
\hline No. & Kecamatan & Reog Dhadhak & Reog Mini & Reog Thek \\
\hline 1 & Ponorogo & 17 & - & - \\
\hline 2 & Siman & 12 & - & - \\
\hline 3 & Babadan & 7 & 1 & - \\
\hline 4 & Jenangan & 11 & 1 & - \\
\hline 5 & Kauman & 4 & 2 & - \\
\hline 6 & Sukorejo & 13 & - & - \\
\hline 7 & Sampung & 11 & 3 & - \\
\hline 8 & Badegan & 5 & 1 & - \\
\hline 9 & Jambon & 5 & 1 & - \\
\hline 10 & Balong & 5 & 1 & - \\
\hline
\end{tabular}


Revitalisasi dalam Fluktuasi... (Luh Putu Kerti Pujani)

\begin{tabular}{|r|l|r|r|c|}
\hline 11 & Nrayun & 5 & 7 & 2 \\
\hline 12 & Slahung & 14 & - & - \\
\hline 13 & Bungkal & 13 & 1 & - \\
\hline 14 & Sambit & 13 & - & 4 \\
\hline 15 & Sawoo & 30 & - & 3 \\
\hline 16 & Mlarak & 6 & 2 & 1 \\
\hline 17 & Jetis & 9 & - & 2 \\
\hline 18 & Pulung & 14 & - & 6 \\
\hline 19 & Sooko & 8 & - & 1 \\
\hline 20 & Ngebel & 4 & 1 & 1 \\
\hline 21 & Pudak & $\mathbf{2 1 6}$ & $\mathbf{2 3}$ & $\mathbf{1 9}$ \\
\hline & Jumlah & & & \\
\hline
\end{tabular}

Sumber: Dinas Pariwisata dan Budaya Kabupaten Ponorogo, 2006.

Grebeg Suro pada Satu Suro (penanggalan Jawa), merupakan momen yang dipilih untuk menyelenggarakan festival reog dalam skala nasional, memperebutkan piala Presiden RI. Acara Grebeg Suro dipusatkan di alun-alun kota Ponorogo selama tiga hari tiga malam, yang dimeriahkan dengan berbagai kesenian tradisional. Masyarakat Ponorogo menaruh simpati terhadap para santri dengan kesenian gajahgajahannya. Implementasi rasa simpati dan penghargaan masyarakat Ponorogo terhadap gagasan para santri, maka setiap perayaan Grebeg Suro kesenian gajah-gajahan selalu dipentaskan, ikut memeriahkan festival reog setiap tahunnya pada Satu Suro.

Festival Nasional Reog Ponorogo pada Grebeg Suro tahun 2007 diikuti oleh 31 peserta/group reog dari seluruh Indonesia. Pesertanya dari provinsi Kalimantan, Sumatera, Sulawesi, Jakarta, Wonogiri, Yogyakarta, Solo, dan Surabaya. Festival diselenggarakan oleh Pemerintah Daerah Tingkat II Ponorogo. Personel tim penilai festival terdiri dari: dua orang seniman asal Ponorogo; satu orang dari Pemerintah Tingkat II Ponorogo; dan dua orang seniman dari luar daerah Ponorogo. Sasaran penilaian adalah; kualitas pementasan, pembina reog terbaik, penata tari terbaik, penata iringan terbaik. Dalam perkembangan selanjutnya tahun 1991 Reog Ponorogo mewakili kerja sama kebudayaan Pemerintah Indonesia dengan pemerintah Amerika Serikat di California. Pada tahun 1992 mewakili pameran kebudayaan di Sevilla Spanyol 
(Utami, 2007: 34). Diplomasi melalui seni budaya dalam penyelenggaraan FIFI ke-35 di Belgia, tidak hanya produk sinema yang dikemukakan tetapi juga kesenian tradisional Jawa Reog Ponorogo turut "go international “ (Bisnis Indonesia, 9 November 2008 Tahun XXIII No : 7852).

Bertolak dari paparan tersebut di atas tampak alur proses perjalanan kesenian reog dari waktu ke waktu. Tampak alur siklus kesenian reog merujuk pada apa yang dikemukakan Capra terkait dengan siklus perkembangan peradaban melalui proses kejadian pertumbuhan,keruntuhan dan disintegrasi. Lanjut Toynbee mengatakan terjadinya suatu peradaban melalui transisi kondisi statis ke aktivitas dinamis (Capra, 1997: 42).

Demikian alur diakronik kesenian reog berfluktuasi. Berkembang, kemudian mengalami krisis dalam bentuk keterasingan, sehingga mengalami stagnasi dan berjarak dengan masyarakat pendukungnya. Siklus ini berulang dua kali putaran yaitu: (a) pada masa penjajahan Belanda, juga pada saat pendudukan Jepang; dan (b) pada tahun 1965 sebagai implikasi keterlibatan terhadap parpol tertentu.

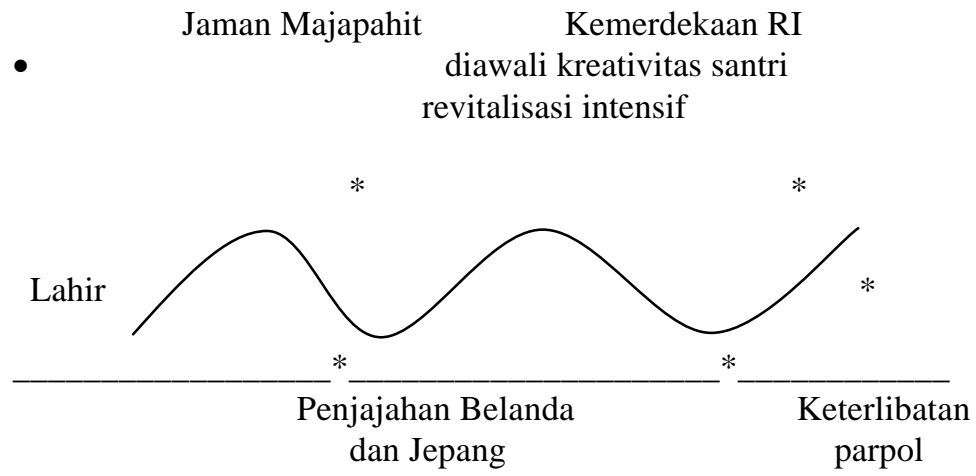

Urutan proses kebangkitan (revitalisasi) pada umumnya seperti yang dikemukakan Wallace juga tampak pada proses kebangkitan kesenian reog. Seperti: pada awalnya kesenian reog berada pada kemapanan tertentu; dominasi kelompok tertentu seperti pemerintah jajahan (Belanda, Jepang), dan partai politik tertentu periode 1965, sehingga reog mengalami krisis dalam artian keterasingan pada titik 
tertentu. Kemudian muncul kreativitas para santri memunculkan satu formulasi baru berupa kesenian gajah-gajahan yang mengambil format pementasan mirip reog dan menyisipkan nafas agamais di dalamnya.

Dalam Pedoman Dasar Kesenian Reog Ponorogo dikemukakan bahwa untuk membendung dominasi kekuatan parpol tertentu terhadap reog pada saat itu muncullah kesenian gajah-gajahan. Di samping itu Utami mengatakan bahwa, kesenian gajah-gajahan mengilhami bangkitnya kesenian reog Ponorogo yang hampir punah. Dengan demikian dapat dikatakan kehadiran kesenian gajah-gajahan merupakan titik balik kebangkitan kesenian Reog Ponorogo dalam siklus fluktuasi yang kedua. Yang kemudian disuport oleh komponen masyarakat Ponorogo lainnya termasuk para ulama, santri dan pemerintah daerah Ponorogo.

Upaya revitalisasi kesenian tradisi, dirasakan lebih tepat bila hal itu sudah merupakan tekad para pendukungnya. Adanya gabungan tangan-tangan kuat seperti seniman, ulama, pemerintah daerah dan industri jasa pariwisata sebagai fenomena kesempatan jaman, yang menghendaki kehadirannya lebih intensif di tengah-tengah masyarakat.

Pewarisan kebudayaan tidak hanya terjadi secara vertikal geneologis (transgenerasi), melainkan dapat pula terjadi secara horizontal. Dalam artian manusia yang satu dapat belajar kebudayaan dari manusia yang lainnya di luar komunitasnya, tanpa ada kaitan geneologis (keturunan Ponorogo) (Poerwanto, 2000: 88). Sehingga reog bisa menembus batas etnis menuju pembesaran skala ke tingkat nasional dan internasional. Terbukti dari peserta festival nasional reog pada Grebeg Suro di Ponorogo. Di mana para peserta festival berasal dari berbagai daerah di Indonesia. Masyarakat luar Ponorogo interes dan mempelajari/mengadopsi kesenian Reog Ponorogo. Sehingga kharisma reog bisa menembus batas etnis menuju pembesaran skala ke tingkat nasional, dan internasional. Dalam proses difusi ini, masyarakat Ponorogo berperan sebagai “point of origin” (Geriya, 1982: 53).

\section{Intensitas Revitalisasi Kesenian Reog Ponorogo}

Langkah-langkah Revitalisasi Intern Masyarakat di Tingkat Desa.

1) Setiap kelurahan di lingkungan kabupaten Ponorogo dianjurkan memiliki padepokan Reog. Setiap padepokan reog diharapkan tampil dalam pementasan reog bulanan yaitu setiap bulan purnama di alun-alun utama kabupaten Ponorogo. Adapun jadwal 
pementasan seluruh padepokan di lingkungan Ponorogo setiap bulannya diatur oleh Dinas Kebudayaan dan Pariwisata Kabupaten Ponorogo.

2) Di kabupaten Ponorogo setiap tahun sekali diselenggarakan upacara bersih desa. Penyelenggaraan upacara ini memiliki makna penghormatan kepada leluhur. Sebelum pementasan reog dimulai diadakan ritual dengan pembacaan mantram nenek moyang (leluhur) yang dilakukan oleh pinisepuh reog. Dengan demikian diharapkan pementasan reog akan menjadi lebih baik.

3) Melakukan latihan rutin terhadap pembarong, khususnya latihan fisik. Melatih urat gigi dan leher, karena beban dalam mengangkat dhadhak merak bertumpu pada gigi dan leher. Pembarong umumnya dilakukan oleh personel tertentu yang berilmu, yang diturunkan oleh pembarong terdahulu.

4) Untuk menekan rutinitas, reog masih memiliki sisi dinamis seperti penambahan tari gambyong pada tari lepas dan tari iring-iringan. Sehingga sama sekali tidak mempengaruhi pakem pementasan reog. Selain itu juga divariasikan dengan lagu campursari (langgam jawa modern). Dengan demikian diharapkan bisa tetap menarik perhatian pengunjung.

Sedangkan langkah-langkah revitalisasi secara formal dari Pemerintah Daerah Tingkat II Ponorogo.

1) Membuat gapura besar bernuansa Reog Ponorogo di setiap perbatasan kota, dan hal ini diteruskan ke tingkat kelurahan dan desa. Gardu-gardu siskamling yang dibangun secara swadaya oleh masyarakat, banyak juga yang dihias dengan nuansa reog. Dengan demikian monumen reog ada di berbagai sudut kota di wilayah Ponorogo. Hal ini merupakan langkah sosialisasi, enkulturasi yang mengakrabkan kesenian Reog Ponorogo terhadap masyarakat pendukungnya yaitu masyarakat Ponorogo.

2) Langkah-langkah institusi nilai-nilai yang terkandung dalam kesenian Reog Ponorogo secara transgenerasi adalah dengan mencantumkan kesenian Reog Ponorogo sebagai mata pelajaran / mata kuliah wajib di sekolah play group sampai dengan perguruan tinggi di kabupaten Ponorogo. Dalam hal ini pembina sanggar memegang peranan aktif dalam pembinaan. Dengan demikian 
sanggar-sanggar dan sekolah-sekolah menjadi tumpuan proses sosialisasi dan enkulturasi kesenian reog dalam rangka revitalisasi sekaligus pelestarian seni budaya reog di Ponorogo. Diharapkan anak-anak sekolah demikian juga para mahasiswa bisa memainkan tari reog dan memahami makna budaya yang terkandung di dalamnya.

3) Personel masyarakat Ponorogo tidak semuanya paham tentang alur cerita yang melatarbelakangi kesenian reog. Demikian juga tidak semuanya faham dengan baik tentang ; tari, peralatan, instrumen, tatanan busana, makna yang terkandung di dalam kesenian reog. Maka dari itu Pemerintah Daerah Tingkat II Ponorogo menyusun sebuah buku yang berjudul; Pedoman Dasar Kesenian Reog Ponorogo Dalam Pentas Budaya Bangsa, kemudian disebar ke sokolah-sekolah.

4) Penerapan busana tokoh reog sebagai busana khas masyarakat Ponorogo dan busana resmi Pemerintah Daerah Tingkat II Ponorogo dalam menghadiri acara adat Ponorogo seperti acara Grebeg Suro.

5) Menyelenggarakan festival nasional Reog Ponorogo setiap Satu Suro. Sebagai upaya rekonstruksi kualitas pementasan Reog Ponorogo dengan menerapkan parameter penilaian seperti; penataan tari, penataan tari iringan, kekompakan dalam pementasan, sistem pembinaan dan seterusnya (Utami, 2007: 10).

Paparan di atas mengarah pada apa yang dikemukakan Soekadijo terkait dengan pengertian revitalization movements, yaitu suatu gerakan atau upaya kebangkitan yang disadari oleh para anggota masyarakat untuk mewujudkan suatu seni budaya yang lebih memuaskan. Upaya kebangkitan kesenian reog menuju kemapanan seni budaya sehingga menjadi icon daerah Ponorogo sedang dibangun oleh masyarakat Ponorogo itu sendiri. Kharisma reog mulai menembus batas etnis menuju kemapanan di Tingkat Nasional ataupun Internasional. Seperti yang diungkapkan oleh Bisnis Indonesia edisi minggu bahwa, kesenian tradisional Jawa Reog Ponorogo go international. Di samping itu reog sudah mulai dilibatkan dalam kegiatan bertaraf Internasional dalam diplomasi seni budaya bangsa. 


\section{SIMPULAN}

Kesenian reog merupakan budaya unggulan daerah Ponorogo. Reog memiliki kekhasan dan sarat dengan nilai luhur yang dibutuhkan dalam kehidupan bermasyarakat. Makna budaya tersebut disandikan melalui simbol-simbol tertentu dalam kesenian reog.

Perjalanan kesenian reog dari waktu ke waktu mengalami fluktuasi. Siklus pertumbuhan dan keruntuhan dalam artian keterasingan, terpinggirkan, dialami dua kali putaran. Upaya menghidupkan kembali (revitalisasi) kesenian reog sebagai budaya unggulan, lebih tepat bila merupakan tekad masyarakat pendukungnya. Melalui gabungan tangantangan kuat seperti: seniman, ulama/santri dan pemerintah daerah menuju kemapanan sebagai icon daerah Ponorogo. Revitalisasi lebih diintensifkan melalui upaya-upaya intern masyarakat desa dan upayaupaya formal dari pemerintah Daerah Tingkat II Ponorogo. Sehingga pada saat ini kharisma reog bisa menembus batas etnis menuju pembesaran skala ke Tingkat Nasional dan Internasional.

\section{DAFTAR RUJUKAN}

Bisnis Indonesia, Edisi Minggu, Edisi 97 Tanggal 9 November 2008 Tahun XXIII No: 7852.

Capra, Fritjof. 1997, Titik Balik Peradaban Sains, Masyarakat dan Kebangkitan Kebudayaan, Yogyakarta: Yayasan Bentang Budaya. Geriya, Wayan. 1982, Teori Antropologi Diakronis Sebuah Ikhtisar, Denpasar: Fakultas Sastra Universitas Udayana.

Kartodirdjo, Sartono. 1977, Metode Penggunaan Bahan Dokumen, dalam Metode-Metode Penelitian Masyarakat, Jakarta: Gramedia.

Koentjaraningrat. 1990, Pengantar Ilmu Antropologi, Jakarta: PT. Rineka Cipta.

Moleong, Lexy J. 2005, Metode Penelitian Kualitatif, Bandung: PT. Remaja Rosdakarya.

Utami, Nurlita Valestri Rahayu. 2007, Pelestarian Kesenian Reog Ponorogo Sebagai Daya Tarik Wisata di Kabupaten Ponorogo Provinsi Jawa Timur, Denpasar: Program Studi Pariwisata Universitas Udayana.

Pemerintah Kabupaten Daerah Tingkat II Ponorogo. 1996, Pedoman Dasar Kesenian Reog Ponorogo dalam Pentas Budaya Bangsa. Ponorogo: Pemda Tingkat II Ponorogo. 
Revitalisasi dalam Fluktuasi... (Luh Putu Kerti Pujani)

Pujani, Luh Putu Kerti. 2000, Pekerja Anak Pada Sektor Informal Penjual Post Card Di Obyek Wisata Tanah Lot, Tabanan, Bali (Studi Tentang Pemaknaan Kerja dalam Perspektif Budaya Kewiraswastaan), Denpasar: Program Pasca Sarjana Universitas Udayana.

Soekadijo, R.G. 1993, Antropologi, Jakarta: Erlangga.

Poerwanto, Hari. 2000, Kebudayaan dan Lingkungan dalam Perspektif Antropologi, Yogyakarta: Pustaka Pelajar

Spradley, James P. 1997, Metode Etnografi, Yogyakarta: PT. Tiara Wacana.

Syaifuddin, Achmad Fedyani. 2005, Antropologi Kontemporer, Suatu Pengantar Kritis Mengenai Paradigma, Jakarta: Prenada Media. Wija, I Gede. 1993, Pelestarian Budaya : Makna dan Implikasinya dalam Proses Regenerasi Bangsa, Denpasar: Upada Sastra. 